\title{
Synovial cyst of dens causing spinal cord compression. Case report
}

\author{
W Choe MD MPH, ${ }^{1}$ I Walot MD ${ }^{2} \mathrm{C}$ Schlesinger MD,${ }^{1}$ I Chambi MD ${ }^{3}$ F Lin MD ${ }^{1}$ \\ Departments of ${ }^{1}$ Pathology, ${ }^{2}$ Radiology and ${ }^{3}$ Division of Neurosurgery, University of \\ California Irvine Medical Center, Irvine, California, USA.
}

\begin{abstract}
We report a rare case of synovial cyst of the dens (odontoid process) in a 61 year old women with no previous history of trauma. She had progressive symptoms of 1 year's duration due to spinal cord compression. Magnetic resonance imaging of cervical spine revealed a large mass posterior to the dens which was compressing the spinal cord near the cervicomedullary junction. This lesion was at first considered radiologically to represent an exuberant pannus formation or a meningioma of the foramen magnum, but subsequent surgical intervention and pathological examination revealed that it was a synovial cyst. Similar cases reported in the literature are reviewed and discussed.
\end{abstract}

Keywords: synovial cyst; spinal cord compression; dens; cervical spine.

\section{Introduction}

Synovial cysts or ganglion cysts of the spine have been described as a rare entity. They are benign lesions adjacent to the facet joints. ${ }^{1}$ Most cases reported in the literature were located in the lumbosacral spine, but those in the cervical spine, similar to our case, are more scarce. Only 10 such cases have been reported in the literature to the best of our knowledge. ${ }^{1-10}$ Here we add another case with a detailed clinical history, radiological studies, and operative pathological findings. We also review the cases reported in the literature and discuss the pathogenesis of this entity.

\section{Case report}

The patient was a 61 year old saleswomen, who had a one year history of numbness of her hands and feet and weakness of the extremities. The left lower extremity was weaker than the right, and the right upper extremity was weaker than the left. She also had progressive difficulty in balancing and lower occipital headache. She denied any history of trauma. Her PPD test was positive and she had a 20-pack-year smok-

Correspondence: Wonsick Choe, MD, Division of Nuclear Medicine H0101, Stanford University Hospital, Stanford, CA 94305-5281, USA. ing history. General physical examination was within normal limits and there were no stigmata of rheumatoid arthritis.

Neurologically, she was alert and oriented and she had intact cranial nerves and normal extraocular muscle movements. Motor strength of the left lower and right upper extremities was weaker than the corresponding contralateral sides. Sensation was intact to pin prick throughout, but there was a decrease of light touch sensation on the right upper extremity compared with the left. The lower extremities had decreased but equal light touch sensation. The knee jerks were $3+$ and the ankle jerks were $2+$. Toes were downgoing bilaterally. Finger-to-nose testing was impaired bilaterally with mild dysmetria. Horizontal tremor was observed, the left being more prominent than the right. Rapid alternating movement and heel-to-shin testings were also impaired bilaterally. Romberg sign was positive with falling to the left. Her gait was moderately ataxic. Nerve conduction velocity tests and an electromyogram were normal. A magnetic resonance (MR) examination of the cervical spine was performed on a 1.5 Tesla imaging system (Fig 1). T1-weighted sagittal images revealed a well circumscribed, extra-axial, homogeneous mass posterior to the dens (odontoid process). The mass was causing marked cervical canal stenosis, and deformed and compressed the spinal cord. On T1-weighted images, the mass was of intermediate signal intensity (hyperintense with respect to cerebrospinal fluid). On T2-weighted images, the mass was of homogeneously low signal intensity (hypointense with respect to 


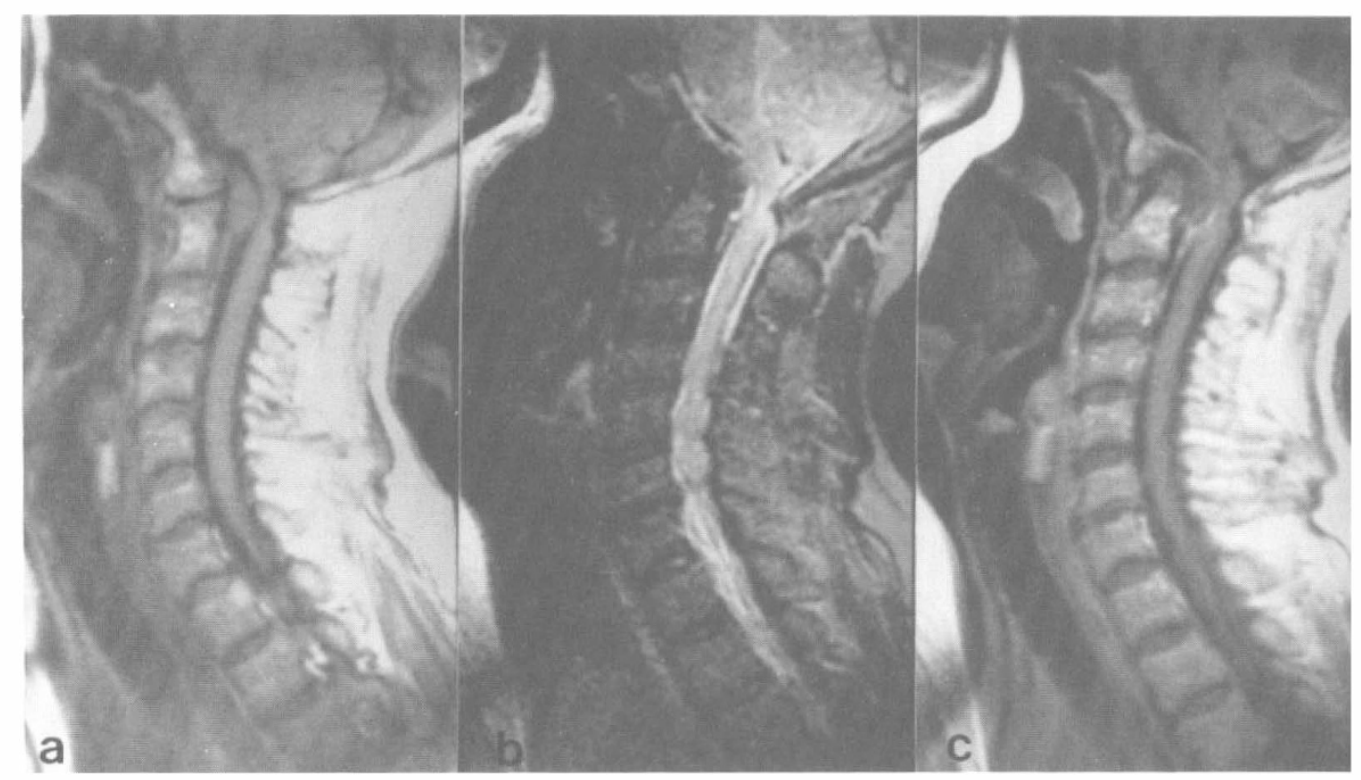

Figure 1 MR examination of the cervical spine. (a) T1-weighted sagittal image showing intermediate signal intensity mass posterior to the dens. (b) T2-weighted sagittal image shows mass to be of low signal intensity. (c) Postgadolinium-DTPA image. Mass shows rim enhancement.

CSF). Postcontrast (Gadolinium-DTPA) T1weighted sagittal images showed a thin rim of enhancement, but no internal enhancement. Questionable erosive changes were noted in the superior aspect of the dens, but the marrow signal within the dens was normal. In addition, a prominent disk bulge at the $\mathrm{C} 4-5$ level deformed the thecal sac and caused effacement of the CSF spaces anterior and posterior to the spinal cord. The spinal cord was not deformed. Spondylotic changes and neuroforaminal encroachment were also noted at other levels of the cervical spine. An exploratory surgical operation by a transoral approach was performed. At surgery, the arch of $\mathrm{Cl}$ was removed. After section of the apical and alar ligaments, the dens, which was intact, was also removed. A yellowish, amorphous, avascular mass-like lesion came into view. The mass was removed in a piecemeal fashion until the tectorial membrane was visualized. Multiple fragments of soft tissue obtained from the operative site consisted of fibroconnective, ligamentous, and cartilagenous tissue, and fragments of bone and skeletal muscle. Histologically, the most remarkable finding was the presence of multicystic structure that was lined by synovial cells. This cystic structure was situated among the loose connective tissue and adjacent to the degenerative cartilagenous tissue. There was no evidence of inflammation, granuloma, or remote hemorrhage. Although the fusion of the vertebrae was inevitable to stabilize the craniovertebral junction and the upper cervical spines, the strength and sensation in her arms and legs returned soon after surgery.

\section{Discussion}

A synovial cyst differs from a ganglion cyst. The former has synovial lining cells and contains clear fluid, whereas the latter is lined by fibrous connective tissue and contains gelatinous and highly viscous fluid. ${ }^{1}$ However, these two terms have been used interchangeably when referring to a benign cystic lesion adjacent to the facet joints of the spine. ${ }^{2}$ Hence, some authors ${ }^{1}$ preferred to use the term 'juxtafacet cyst'. Other benign cystic lesions in this region, quoted from Sypert et al, ${ }^{11}$ include arachnoid cysts, acquired and congenital fibrous cysts, ependymal cysts, teratomatous cysts, and perineural cysts.

The pathogenesis of the ganglion/synovial cysts of the spine has been debated. While some authors ${ }^{3.11-13}$ seemed to imply that trauma was the cause, others had different 
opinions. Other theories pertaining to the pathogenesis, reviewed by Miller et al, ${ }^{6}$ include metaplasia, the presence of developmental rests, excess stress at the facet joints with herniation of synovial tissue, and mucinous degeneration of connective tissue.

Rousseaux et al ${ }^{14}$ reviewed 73 cases from the literature and eight of their own cases. They opined that although these were variously described in the literature as the synovial cyst, ganglion cyst, benign synovialoma, and pigmented villonodular synovitits, they actually represented a spectrum of benign degeneration of soft articular tissues. Indeed, our case, radiographically, presented as a rather solid-appearing mass without significant evidence of cystic nature. At surgery, however, some amorphous material was seen that might represent the cystic content. In addition, the surgical specimen contained a large amount of degenerative cartilagenous tissue. Moreover, our patient did not have a history of trauma, and the MR of the cervical spine revealed that there were other areas of spinal stenosis, possibly degenerative in nature. Another interesting observation was that, in the cases without a history of trauma, the occupations of the patients might involve considerable neck movement: eg factory assembly line worker, dentist, and saleswoman (Table I).

Radiologically, the postgadolinium images are important for the presurgical differential diagnosis of this lesion. Meningiomas, which can occur in this location, may have a similar precontrast appearance, but most often exhibit uniform contrast enhancement. The lack of internal enhancement in this case made meningioma unlikely. The normal marrow signal within the dens also made primary bone pathology unlikely. Given the possible erosive changes in the dens and the well circumscribed

Table I Cases of synovial cysts of the cervical spine reported in the literature

\begin{tabular}{|c|c|c|c|c|c|}
\hline Reference & Age. Sex & Symptoms & Occupation & Trauma & Site \\
\hline Kao et al $(1974)^{1}$ & $52 \mathrm{M}$ & Neck pain & $\begin{array}{c}\text { Factory } \\
\text { assem- } \\
\text { bly line } \\
\text { worker }\end{array}$ & No & $\mathrm{C} 5-7$ \\
\hline $\begin{array}{l}\text { Cartwright et al } \\
(1985)^{3}\end{array}$ & $41 \mathrm{M}$ & Spastic paraparesis & Unknown & $\begin{array}{l}\text { Old fixa- } \\
\text { tion } \\
(C 5-6)\end{array}$ & $\mathrm{C} 7-\mathrm{T} 1$ \\
\hline Jabre et al $(1987)^{5}$ & $60 \mathrm{M}$ & Weakness of legs & Unknown & Yes & C6-7 \\
\hline $\begin{array}{l}\text { Alguacil-Garcia } \\
(1987)^{2}\end{array}$ & $64 \mathrm{~F}$ & Retropharyngeal mass & Unknown & Unknown & $\begin{array}{c}\mathrm{C} 2 \text {, adjacent } \\
\text { to anterior } \\
\text { ligament }\end{array}$ \\
\hline $\begin{array}{l}\text { Onifrio \& Mih } \\
\quad(1988)^{8}\end{array}$ & $73 \mathrm{M}$ & $\begin{array}{l}\text { Paresthesia of both } \\
\text { upper extremities }\end{array}$ & Dentist & Unknown & $\begin{array}{l}\text { Quadrate } \\
\text { ligament } \\
\text { of dens }\end{array}$ \\
\hline $\begin{array}{l}\text { Patel \& Sanders } \\
(1988)^{9}\end{array}$ & $42 \mathrm{~F}$ & $\mathrm{R}$ neck pain & Unknown & No & $\mathrm{C} 4-5$ \\
\hline Miller et al $(1989)^{6}$ & $67 \mathrm{~F}$ & $\begin{array}{l}\text { Neck pain, decrease } \\
\text { of ambulation }\end{array}$ & Unknown & Unknown & $\mathrm{C} 1-2$ \\
\hline $\begin{array}{l}\text { Nijensohn et al } \\
(1990)^{7}\end{array}$ & $58 \mathrm{M}$ & $\begin{array}{l}\text { Weakness of RUE } \\
\text { and both LE's }\end{array}$ & Unknown & Unknown & $\mathrm{C} 5-6$ \\
\hline $\begin{array}{l}\text { Quaghebeur \& Jef- } \\
\text { free }(1992)^{10}\end{array}$ & $82 \mathrm{~F}$ & Leg weakness & Unknown & Unknown & $\mathrm{C} 1-2$ \\
\hline Goffin et al $(1992)^{4}$ & $65 \mathrm{M}$ & $\begin{array}{l}\text { Paresthesis of upper } \\
\text { limbs }\end{array}$ & Unknown & Unknown & $\mathrm{C} 1-2$ \\
\hline $\begin{array}{l}\text { Choe et al (1993) } \\
\text { (this paper) }\end{array}$ & $61 \mathrm{~F}$ & $\begin{array}{l}\text { Weakness, numbness } \\
\text { of extremities }\end{array}$ & $\begin{array}{l}\text { Sales- } \\
\text { woman }\end{array}$ & No & Dens \\
\hline
\end{tabular}


benign appearance of the lesion, pannus formation was thought to be a possible etiology. The acute accumulation of synovial fluid associated with rheumatoid arthritis shows a similar appearance. The appearance of $1 \mathrm{a}$ and $1 \mathrm{~b}$ in Figure 1 suggests a pseudotumour, and a review of the literature of masses in this region was given by Crockard et al..$^{15}$

In recent years, a number of papers have commented on the MR appearance of synovial cysts of the lumbar, ${ }^{16-21}$ thoracic, ${ }^{22}$ and cervical spine. ${ }^{6,9}$ Synovial cysts are generally reported to have signal characteristics of typical 'cysts', that is, low to intermediate signal intensity on T1-weighted images and high signal intensity on T2-weighted images. However, there are other reports of synovial cysts which are of low signal intensity on T2-weighted images. ${ }^{17}$ This is usually attributed to hemorrhage and blood products within the cyst contents. However, it may not be necessary to postulate previous hemorrhage as the aetiology of this lesion's appearance on the T2-weighted sequence. The lesion itself is a simple cyst in name only, that is, it consists of multiple small infolded cystic spaces. Mucoid material can also have variable T2 signal characteristics; for instance, it is reported in MR imaging of the paranasal sinuses. The postgadolinium appearance of synovial cysts has also been reported to be variable, with rim enhancement reported as one of the patterns. ${ }^{14}$ There is another report of a synovial cyst with a similar appearance (T1-weighted images only) at the crainiovertebral junction, and George et al recently discussed synovial cysts of the lateral mass in the craniovertebral junction in their monograph on tumours of the foramen magnum. ${ }^{23}$

As far as management is concerned, we should be aware that this is a benign lesion that only requires surgical intervention with excellent prognosis.

Sypert et al ${ }^{11}$ expressed their surprise that this type of cyst was not seen more commonly, considering the relatively high incidence of injury to the facet joint. With the advent of new diagnostic modalities such as CT and MR imagings, more cases could be encountered in the future.

\section{References}

1 Kao CC, Winkler SS, Turner JH (1974) Synovial cyst of spinal facet. J Neurosurg 41: 372-376.

2 Alguacil-Garcia A (1987) Spinal synovial cyst (ganglion). Am J Surg Pathol 11: 732-735.

3 Cartwright MJ, Nehls DG, Carrion CA. Spetzler RF (1985) Synovial cyst of a cervical facet joint: case report. Neurosurgery 16: 850-859.

4 Goffin J, Wilms G. Plets C, Bruneel B, Casselman J (1992) Synovial cyst at the C1-C2 junction. Neurosurgery 30: 914-916.

5 Jabre A, Shahbabian S, Keller JT (1987) Synovial cyst of the cervical spine. Neurosurgery 20: 316-8.

6 Miller JD, Al-Mefty O, Middleton TH (1989) Synovial cyst at the craniovertebral junction. Surg Neurol 31: 239-42.

7 Nijensohn E, Russell EJ, Milan M, Brown T (1990) Calcified synovial cyst of the cervical spine: CT and MR evaluation. J Compute Assist Tomogr 14: 473-476.

8 Onofrio BM, Mih AD (1988) Synovial cyst of the spine. Neurosurgerv 22: 642-647.

9 Patel SC, Sanders WP (1988) Synovial cyst of the cervical spine: case report and review of the literature. AJNR 9: 602-603.

10 Quaghebeur G, Jeffree M (1992) Synovial cyst of the high cervical spine causing myelopathy. $A J N R$ 13: 981-982.

11 Sypert GW, Leech RW, Harris AB (1973) Posttraumatic lumbar epidural true synovial cyst. J Neurosurg 39: 246-248.

12 Pendleton B, Carl B, Pollay M (1983) Spinal extradural benign synovial or ganglion cyst: case report and review of the literature. Neurosurgery 13: $322-326$.

13 Brish A, Payan HM (1972) Lumbar intraspinal extradural ganglion cyst. J Neurol Neurosurg Psychiatry 35: $771-775$

14 Rousseaux P, Durot JF, Pluot M, Bernard MH. Scherpereel B, Bazin A et al (1989) Kystes synoviaux et synovialomes du rachis lombaire. Neurochirurgie 35: 31-39.

15 Crockard HA, Sett P, Geddes JF, Stevens JM, Kendall BE, Pringle JAS (1991) Damaged ligaments at the craniocervical junction presenting as an extradural tumour: a differential diagnosis in the elderly. $J$ Neurol Neurosurg Psychiatry 54: 817-821.

16 Azzam CJ (1988) Midline lumbar ganglion/synovial cyst mimicking an epidural: case report and review of pathogenesis. Neurosurgery 23: 232-234. 
17 Jackson DJr. Atlas SW, Mani JR. Norman D (1989) Intraspinal synovial cysts: MR imaging. Radiology 170: $527-530$.

18 Lui SS. Williams KD. Drayer BP. Spetzler RF. Sonntag VKH (1989) Synovial cysts of the lumbosacral spine: diagnosis by MR imaging. AJNR 10: $12.39-12.42$.

19 Rosenblum J. Mojtahedi S. Foust RJ (1989) Synovial cysts in the lumbar spine: MR characteristics. AJNR 10: S94.

20 Ross JS. Modic MT. Masaryk TJ. Carter J. Marcus RE. Bohlman H (1989) Assessment of extradural degenerative disease with Gd-DTPA-enhanced MR imaging: correlation with surgical and pathological findings. AJNR 10: $1243-1249$.

21 Yuh WC. Drew JM. Weinstein JN. McGuire CW. Moore TE. Kathol MH et al (1991) Intraspinal synovial cysts: magnetic resonance evaluation. Spine 16: 740-745.

22 Awwad EE. Martin DS, Bucholz RD. Murali S (1991) Synovial cyst of the midthoracic spine. AJNR 12: $562-563$.

23 George B, Lot G. Velut S (1993) Tumours of the foramen magnum. Neurochirurgie 39; suppl 1: 1-91. 